\title{
Determination of Mineral Elements in Nanyang Mugwort (Artemisia argyi) Leaves Harvested from Different Crops by Inductively Coupled Plasma Mass Spectrometry and Inductively Coupled Plasma Atomic Emission Spectrometry
}

\author{
Chao Li, ${ }^{a}$ Zhan-hu Cui, ${ }^{b}$ Zhe Li, ${ }^{c}$ Li Gao, ${ }^{a}$ Chao-yun Zhang, ${ }^{a}$ Dan-xia Li, ${ }^{a}$ \\ Zhong-ming Zhang, ${ }^{a}$ and Xian-zhang Huang*,a
}

${ }^{a}$ Henan Province Key Laboratory of Zhang Zhongjing Formulae and Herbs for Immunoregulation, Nanyang Institute of Technology; Nanyang 473004, China: ${ }^{b}$ College of Agriculture, Fujian Agriculture and Forestry University; Fuzhou 350002, China: and ${ }^{c}$ Tang-ai Ecological Agriculture Development Limited Liability Company; Nanyang 473400, China. Received October 29, 2020; accepted January 16, 2021; advance publication released online January 30, 2021

\begin{abstract}
Due to high need for medical purposes, multiple harvests of mugwort (Artemisia argyi) have been extensively applied in China for the increase of mugwort yield recently. However, the investigation on the mineral elements in different crops, which are significantly related to mugwort growth and the clinical efficacy of this medicinal herb, has not been conducted. This study provided an analytical method and quality evaluation for mineral elements in Nanyang mugwort leaves harvested from three different crops. The contents of 35 mineral elements were determined by inductively coupled plasma mass spectrometry (ICP-MS) and inductively coupled plasma atomic emission spectrometry (ICP-AES). ANOVA, principal component analysis and factor analysis were applied to evaluate the results. Four principal components were identified and their comprehensive evaluation function was as follows: $F=0.7008 F 1+0.1236 F 2+0.0936 F 3+0.0321 F 4$. The comprehensive scores of the mugwort leaves from different crops were ranked as follows: 3 rd crop $>2$ nd crop $\approx 1$ st crop. These findings can provide a reference for the quality control and clinical use of mugwort leaves, and a guidance of differential nourishing strategies for different crops.
\end{abstract}

Key words Artemisia argyi; mineral element; quality evaluation

\section{Introduction}

Traditional mugwort leaves are dried leaves of Artemisia argyi Levl. et Vant., an annual plant of the Artemisia genus of the Asteraceae family endemic to northern temperate regions. They are widely used as dietary functional material, food flavoring and coloring agent in China, Japan, Korea and other East Asian countries. ${ }^{1-3)}$ They can also be used both orally and externally for medical purposes, such as channeled to the liver, spleen and kidney. ${ }^{4)}$ They are proved to have various clinical effects, e.g., meridian warming, bleeding stopping, cold dispersing, pain relieving, and miscarriage preventing. ${ }^{5-8)}$ Therefore, the mugwort leaves market grew at a rate of $30 \%$ during the last 10 years. Due to the high need, multiple crops for mugwort leaves within a year is developed in Nanyang, the lasrgest mugwort leaves base in China. Based on the long-term cultivation practices of our research group, Nanyang mugwort is generally harvested at a height of $90 \mathrm{~cm}$ and grown in three crops per year. However, the quality of mugwort leaves from each crop for the consumption and clinical application has not been analyzed.

Previous studies of annual mugwort leaves have focused on the chemical components and their pharmacological effects. $^{9-13)}$ This study provided the contents of 35 mineral elements in mugwort leaves from three crops have been determined by inductively coupled plasma mass spectrometry (ICP-MS) and inductively coupled plasma atomic emission spectrometry (ICP-AES). The results can provide a rational basis and useful supplement for the quality control and evaluation of mugwort leaves.

\section{Results and Discussion}

The validation data for the analytical procedure was summarized in Table S1. Each element showed a good linear relationship, low detection limit, and reasonable linear range, indicating that the experimental method meet the analytical requirements. In addition, the relative standard deviation (RSD) values were below 3.06\%, and their recoveries were 98.66-102.17\%.

The contents of 35 kinds of mineral elements in mugwort leaves from the 1st, 2nd and 3rd crops were determined and ANOVA and multiple comparisons (Table 1). The overall quality score of each element showed the following order: $\mathrm{K}>\mathrm{C}$ $\mathrm{a}>\mathrm{Mg}>\mathrm{Al}>\mathrm{Fe}>\mathrm{Mn}>\mathrm{Na}>\mathrm{Cu}>\mathrm{Sr}>\mathrm{Zn}>\mathrm{Ba}>\mathrm{Ti}>\mathrm{Cr}>\mathrm{Ni}>\mathrm{V}>$ $\mathrm{Mo}>\mathrm{La}>\mathrm{Pb}>\mathrm{Zr}>\mathrm{As}>\mathrm{Y}>\mathrm{Co}>\mathrm{Cd}>\mathrm{Sc}>\mathrm{Sn}>\mathrm{Ga}>\mathrm{Nb}>\mathrm{Tl}>\mathrm{Be}>$ $\mathrm{Sb}>\mathrm{Bi}>\mathrm{Ge}>\mathrm{Ag}>\mathrm{Hg}>\mathrm{Se}$. Duncan analysis showed that the contents of $\mathrm{Mo}, \mathrm{La}$ and $\mathrm{Tl}$ in leaves were significantly different between the 1 st crop and the 2 nd crop $(p<0.05)$, while the contents of the remaining 32 elements were about same $(p>0.05)$. The contents of $\mathrm{Ca}, \mathrm{Al}, \mathrm{Fe}, \mathrm{Sr}, \mathrm{Ba}, \mathrm{Ti}, \mathrm{Cr}, \mathrm{V}, \mathrm{La}$, $\mathrm{Pb}, \mathrm{Zr}, \mathrm{As}, \mathrm{Y}, \mathrm{Co}, \mathrm{Cd}, \mathrm{Sc}, \mathrm{Sn}, \mathrm{Ga}, \mathrm{Tl}, \mathrm{Bi}, \mathrm{Ge}, \mathrm{Ag}, \mathrm{Hg}$ and $\mathrm{Se}$ dramatically differed between the 1st crop and the 3rd crop; and the contents of $\mathrm{Ca}, \mathrm{Al}, \mathrm{Fe}, \mathrm{Cu}, \mathrm{Sr}, \mathrm{Zn}, \mathrm{Ba}, \mathrm{Ti}, \mathrm{V}, \mathrm{La}, \mathrm{Pb}$, $\mathrm{Zr}, \mathrm{As}, \mathrm{Y}, \mathrm{Co}, \mathrm{Sc}, \mathrm{Sn}, \mathrm{Ga}, \mathrm{Be}, \mathrm{Bi}, \mathrm{Sb}, \mathrm{Ge}, \mathrm{Ag}, \mathrm{Hg}$ and $\mathrm{Se}$ largely change from the 2 nd crop to the 3 rd crop. In terms of accumulation pattern, mineral contents in leaves were similar from the 1 st crop to the 2 nd crop, but largely different to those from the 3rd crop.

$\mathrm{K}, \mathrm{Ca}, \mathrm{Mg}, \mathrm{Fe}, \mathrm{Mn}, \mathrm{Cu}, \mathrm{Ni}$ and $\mathrm{Mo}$, which are essential mineral elements for plant growth, ${ }^{14,15)}$ showed low variation 
Table 1. Analytical Results and Differential Analysis

\begin{tabular}{|c|c|c|c|c|}
\hline \multirow{2}{*}{ Element } & \multirow{2}{*}{ Unit } & \multicolumn{3}{|c|}{ Mineral element content (Mean \pm S.D., $n=6$ ) } \\
\hline & & First crop & Second crop & Third crop \\
\hline K & $\mathrm{g} / \mathrm{kg}$ & $34.591 \pm 0.642 \mathrm{a}$ & $29.816 \pm 3.907 \mathrm{a}$ & $37.674 \pm 8.286 \mathrm{a}$ \\
\hline $\mathrm{Ca}$ & & $13.526 \pm 0.576 b$ & $12.528 \pm 1.270 \mathrm{~b}$ & $19.340 \pm 4.588 \mathrm{a}$ \\
\hline $\mathrm{Mg}$ & & $3.824 \pm 0.210 \mathrm{a}$ & $3.487 \pm 0.325 \mathrm{a}$ & $3.892 \pm 0.853 \mathrm{a}$ \\
\hline $\mathrm{Al}$ & & $1.724 \pm 0.033 b$ & $1.385 \pm 0.280 \mathrm{~b}$ & $5.264 \pm 0.301 \mathrm{a}$ \\
\hline $\mathrm{Fe}$ & & $0.618 \pm 0.002 b$ & $0.530 \pm 0.062 b$ & $1.527 \pm 0.169 a$ \\
\hline $\mathrm{Mn}$ & & $0.138 \pm 0.005 \mathrm{a}$ & $1.570 \pm 0.030 \mathrm{a}$ & $1.522 \pm 0.029 \mathrm{a}$ \\
\hline $\mathrm{Na}$ & $\mathrm{mg} / \mathrm{kg}$ & $73.546 \pm 8.881 \mathrm{a}$ & $82.638 \pm 9.607 \mathrm{a}$ & $79.916 \pm 23.904 a$ \\
\hline $\mathrm{Cu}$ & & $41.145 \pm 2.146 \mathrm{ab}$ & $45.770 \pm 5.708 \mathrm{a}$ & $33.998 \pm 6.127 b$ \\
\hline $\mathrm{Sr}$ & & $36.648 \pm 1.548 b$ & $38.858 \pm 3.351 b$ & $56.977 \pm 14.445 \mathrm{a}$ \\
\hline $\mathrm{Zn}$ & & $35.433 \pm 1.737 \mathrm{ab}$ & $31.246 \pm 2.248 \mathrm{~b}$ & $45.333 \pm 9.711 \mathrm{a}$ \\
\hline $\mathrm{Ba}$ & & $32.473 \pm 0.900 \mathrm{~b}$ & $28.551 \pm 2.092 b$ & $57.799 \pm 12.547 \mathrm{a}$ \\
\hline $\mathrm{Ti}$ & & $29.585 \pm 3.112 b$ & $22.241 \pm 2.089 b$ & $59.947 \pm 14.078 \mathrm{a}$ \\
\hline $\mathrm{Ni}$ & & $3.062 \pm 1.672 \mathrm{a}$ & $2.491 \pm 1.233 \mathrm{a}$ & $1.619 \pm 0.317 \mathrm{a}$ \\
\hline $\mathrm{Cr}$ & & $4.104 \pm 0.656 b$ & $4.414 \pm 0.919 \mathrm{ab}$ & $5.691 \pm 0.574 a$ \\
\hline $\mathrm{V}$ & & $2.272 \pm 0.189 b$ & $1.677 \pm 0.226 \mathrm{~b}$ & $5.893 \pm 0.845 \mathrm{a}$ \\
\hline Mo & & $1.138 \pm 0.159 \mathrm{a}$ & $0.851 \pm 0.090 \mathrm{~b}$ & $0.941 \pm 0.081 \mathrm{ab}$ \\
\hline $\mathrm{La}$ & & $1.174 \pm 0.031 b$ & $0.786 \pm 0.099 \mathrm{c}$ & $2.042 \pm 0.225 \mathrm{a}$ \\
\hline $\mathrm{Pb}$ & & $0.939 \pm 0.122 b$ & $1.296 \pm 0.090 \mathrm{~b}$ & $2.187 \pm 0.533 a$ \\
\hline $\mathrm{Zr}$ & & $0.888 \pm 0.099 b$ & $0.675 \pm 0.048 b$ & $1.818 \pm 0.292 \mathrm{a}$ \\
\hline As & & $0.552 \pm 0.011 b$ & $0.451 \pm 0.012 b$ & $1.148 \pm 0.168 \mathrm{a}$ \\
\hline $\mathrm{Y}$ & & $0.502 \pm 0.038 b$ & $0.383 \pm 0.545 b$ & $1.100 \pm 0.157 \mathrm{a}$ \\
\hline Co & & $0.316 \pm 0.067 b$ & $0.198 \pm 0.028 b$ & $0.502 \pm 0.081 \mathrm{a}$ \\
\hline $\mathrm{Sc}$ & & $0.156 \pm 0.025 b$ & $0.099 \pm 0.003 b$ & $0.352 \pm 0.090 \mathrm{a}$ \\
\hline $\mathrm{Cd}$ & & $0.180 \pm 0.003 b$ & $0.209 \pm 0.008 \mathrm{ab}$ & $0.296 \pm 0.079 a$ \\
\hline $\mathrm{Sn}$ & & $0.132 \pm 0.013 b$ & $0.100 \pm 0.014 b$ & $0.220 \pm 0.061 \mathrm{a}$ \\
\hline $\mathrm{Ga}$ & & $0.131 \pm 0.007 b$ & $0.097 \pm 0.014 b$ & $0.302 \pm 0.032 \mathrm{a}$ \\
\hline $\mathrm{Nb}$ & & $0.127 \pm 0.019 \mathrm{a}$ & $0.392 \pm 0.052 \mathrm{a}$ & $0.227 \pm 0.054 \mathrm{a}$ \\
\hline $\mathrm{Tl}$ & $\mu \mathrm{g} / \mathrm{kg}$ & $36.506 \pm 10.255 b$ & $73.991 \pm 8.332 \mathrm{a}$ & $57.479 \pm 12.439 a$ \\
\hline $\mathrm{Be}$ & & $27.771 \pm 6.944 \mathrm{ab}$ & $17.623 \pm 4.969 b$ & $34.353 \pm 10.375 \mathrm{a}$ \\
\hline $\mathrm{Sb}$ & & $31.183 \pm 3.534 \mathrm{ab}$ & $28.323 \pm 0.377 \mathrm{~b}$ & $33.460 \pm 1.792 \mathrm{a}$ \\
\hline $\mathrm{Bi}$ & & $32.670 \pm 2.137 b$ & $31.282 \pm 1.120 \mathrm{~b}$ & $61.480 \pm 9.099 \mathrm{a}$ \\
\hline $\mathrm{Ge}$ & & $14.766 \pm 0.669 \mathrm{~b}$ & $11.222 \pm 1.666 \mathrm{~b}$ & $29.536 \pm 3.582 \mathrm{a}$ \\
\hline $\mathrm{Ag}$ & & $13.010 \pm 1.661 \mathrm{~b}$ & $11.833 \pm 1.841 \mathrm{~b}$ & $56.369 \pm 16.137 \mathrm{a}$ \\
\hline $\mathrm{Hg}$ & & $11.188 \pm 0.872 b$ & $9.994 \pm 0.629 b$ & $19.515 \pm 2.425 \mathrm{a}$ \\
\hline $\mathrm{Se}$ & & $3.305 \pm 0.712 b$ & $2.687 \pm 0.651 b$ & $6.863 \pm 0.143 a$ \\
\hline
\end{tabular}

Note: Different lowercase letters indicate that the difference is statistically significant $(p<0.05)$. S.D.: standard deviation.

coefficients, suggesting that they accumulate in the leaves of different crops most likely, these elements behave as the most important limiting factors for the growth of mugwort leaves. Regarding to the heavy metals, the contents of $\mathrm{Pb}, \mathrm{Cd}, \mathrm{Hg}$ and As were below the specified limits according to Chinese pharmacopoeia regulations (the content of $\mathrm{Pb}, \mathrm{Cd}, \mathrm{As}, \mathrm{Hg}$ and $\mathrm{Cu}$ should not be higher than $5.0,1.0,2.0,0.2$ and $20.0 \mathrm{mg} / \mathrm{kg}$, respectively). ${ }^{4)}$ While, the content of $\mathrm{Cu}$ exceeded the limit by 2 to 3 -fold. This may be explained by the $\mathrm{Cu}$-enriching capability of leaves, or the high $\mathrm{Cu}$ content of the soil or environment.

Principal component analysis was further performed to explore the relationships between the mineral elements in the mugwort leaves from different crops. As shown in Table S2, four principal components were extracted with a cumulative variance contribution of $94.991 \%$, indicating that the four principal components comprehensively reflect the overall information of the mineral elements. The variance contributions of four principal components were as follows: $\mathrm{F}=0.7008 \mathrm{~F} 1+$ $0.1236 \mathrm{~F} 2+0.0936 \mathrm{~F} 3+0.0321 \mathrm{~F} 4$. The values of Fs from the 3rd crop were generally highest, while those from the 1st or 2nd crop were lower and overlapped (as shown in Table S3). The order of the weighted scores of the comprehensive evaluation function was as follows: the 3rd crop (2.504) $>$ the 2 nd crop $(-1.217) \approx$ the 1 st crop $(-1.286)$. The observed results indicate that the accumulation and distribution of mineral elements in the mugwort leaves from the 3rd crop are much higher than those from the 1st or 2nd crop. They may be closely correlated to the growth period of each crop (around 50, 60 and $90 \mathrm{~d}$ to the 1st, 2nd and 3rd crop, respectively).

\section{Conclusion}

The current study revealed that the mineral elements in the mugwort leaves from 3rd crop are highly enriched compared to the 1 st or 2 nd crop, indicating that the longer growth period enables greater accumulation of mineral elements in the leaves. The results provide supportive information for the quality control and safety evaluation of mugwort leaves. Further comprehensive evaluation of mugwort leaves by combining the contents of mineral elements and active ingredients should be further considered. 


\section{Experimental}

Plant Material Nanyang mugwort plant was cultivated in the mugwort production base of the Tang'ai Ecological Agriculture Development Corporation and harvested when reaching a plant height of approximately $90 \mathrm{~cm}$. The harvested time of the 1st, 2nd and 3rd crop was in mid-June, mid-August and mid-November of 2019. After collection, the leaves were dried and thoroughly grinded.

Sample Digestion Approximately $0.4 \mathrm{~g}$ of mugwort leaf sample was weighed and placed in a digestion tank. The sample was treated with $5 \mathrm{~mL}$ of $\mathrm{HNO}_{3}$ (guaranteed-reagent pure, Merk, Germany) overnight, incubated at $160^{\circ} \mathrm{C}$ for $6 \mathrm{~h}$. After cooling down, the acid was evaporated, the digestion was then transferred into a $25 \mathrm{~mL}$ volumetric flask. A controlled sample was set up by the same procedure. The controlled and digested samples were injected into the instrument for analysis.

Measurement Parameters The working parameters of ICP-MS (Model Thermo X Series II, Thermo Fisher Scientific, U.S.A.) were as follows: radio frequency (RF) power: $1200 \mathrm{~W}$; atomizer pressure: $1.0 \mathrm{bar}$; auxiliary gas flow rate: $0.7 \mathrm{~L} / \mathrm{min}$; plasma gas flow rate: $13.0 \mathrm{~L} / \mathrm{min}$; peristaltic pump speed: $30 \mathrm{r} / \mathrm{min}$ for analysis and $70 \mathrm{r} / \mathrm{min}$ for flushing. The working parameters of ICP-AES (Model ICA P-6300, Thermo Electron, Beverly, MA, U.S.A.) were as follows: RF power: $1150 \mathrm{~W}$; peristaltic pump speed: $50 \mathrm{r} / \mathrm{min}$; auxiliary gas flow rate: $0.5 \mathrm{~L} / \mathrm{min}$; atomizer gas flow rate: $0.7 \mathrm{~L} / \mathrm{min}$.

Acknowledgments This work was supported by Grants from NSFC (81803661), Scientific and Technological Key Project of Henan Province (182102110361 and 202102310512), and traditional Chinese medicine industry technology system of Henan Province.

Conflict of Interest The authors declare no conflict of interest.

Supplementary Materials The online version of this article contains supplementary materials.

\section{References}

1) Kim J., Shin E., Lim H., Choi S., Kim C., Suh S., Kim C., Park G., Park C., Kim H., Choi J., Song S., Shin D., J. Anal. Methods Chem., 4, 916346-916951 (2015).

2) Song X., Wen X., He J., Zhao H., Li S., Wang M., Funct. Food, 52, 648-662 (2019)

3) Mei Q., Chen X., Xiang L., Liu Y., Su Y., Gao Y., Dai W., Dong P., Chen S., Biol. Pharm. Bull., 39, 1531-1537 (2016).

4) Chinese Pharmacopoeia Commission of China, "Pharmacopoeia of the People's Republic of China," Vol. 1, Chinese Medical Science and Technology Press, Beijing, 2015, pp. 89-90.

5) Seo J., Kang H., Son K., Kim J., Lee C., Kim H., Kwon B., Planta Med., 69, 218-222 (2003).

6) Xu J., Lu J., Guo S., Med. Plant, 7, 13-16 (2016).

7) Liu D., Chen Y., Wan X., Shi N., Huang L., Wan D., J. Tradit. Chin. Med., 4, 20-23 (2017).

8) Xiao J., Liu W., Sun H., Li W., Zhang J., Bioorg. Chem., 92, 103268-103277 (2019).

9) Zeng K., Wang S., Dong X., Jiang Y., Tu P., Phytomedicine, 21, 298-306 (2014).

10) Xin Y., Zhang M., Yang H., Adhikari B., J. Food Sci. Technol., 1, 249-257 (2015)

11) Lv J., Li Z., Zhang L., Nat. Prod. Res., 32, 632-639 (2018).

12) Xiang F., Bai J., Tan X., Chen T., Yang W., He F., Ind. Crops Prod., 125, 582-587 (2018).

13) Tseng C., Huang Y., Chang Y., Liao H., Hsieh P., J. Food Drug Anal., 28, 115-123 (2020).

14) Njinga R., Moyo M., Abdulmaliq S., Int. J. Agron., 3, 1-9 (2013).

15) Esetlili B., Pekcan T., Çobanoğlu O., Aydoğdu E., Turan S., Anac D., Tarim. Tarim. Bilim. Derg., 20, 239-247 (2014). 